\title{
Sewage Sludge as N-Fertilizers for Crop Production Enabling the Circular Bioeconomy in Agriculture: A Challenge for the New EU Regulation 1009/2019
}

\author{
Mirko Cucina ${ }^{1, *}$, Patrizia De Nisi ${ }^{1}$, Simone Sordi ${ }^{2}$ and Fabrizio Adani ${ }^{1, *}$ (D) \\ 1 Gruppo Ricicla Lab., DiSAA, Università degli Studi di Milano, Via Celoria 2, 20133 Milano, Italy; \\ patriza.denisi@unimi.it \\ 2 ACS Dobfar SpA, Viale Addetta 13-Tribiano, 20067 Milano, Italy; simone.sordi@acsdobfar.it \\ * Correspondence: mirko.cucina@unimi.it (M.C.); fabrizio.adani@unimi.it (F.A.)
}

Citation: Cucina, M.; De Nisi, P.; Sordi, S.; Adani, F. Sewage Sludge as N-Fertilizers for Crop Production Enabling the Circular Bioeconomy in Agriculture: A Challenge for the New EU Regulation 1009/2019.

Sustainability 2021, 13, 13165. https: / / doi.org/10.3390/su132313165

Academic Editors: Rajeev

Pratap Singh, Megharaj Mallavarapu,

Vaibhav Srivastava, Surindra

Singh Suthar and Vinod Kumar Garg

Received: 8 November 2021

Accepted: 24 November 2021

Published: 27 November 2021

Publisher's Note: MDPI stays neutral with regard to jurisdictional claims in published maps and institutional affiliations.

Copyright: (c) 2021 by the authors. Licensee MDPI, Basel, Switzerland. This article is an open access article distributed under the terms and conditions of the Creative Commons Attribution (CC BY) license (https:/ / creativecommons.org/licenses/by/ $4.0 /)$.

\begin{abstract}
The fertilizer framework in the European Union has recently been reviewed by EU Regulation 1009/2019 that excluded sewage sludge from the list of the possible constituents of organic fertilizers relying on their origin, not on their quality. This paper aimed to carry out a complete characterization of sewage sludge obtained from a pharmaceutical manufacturing process (PDSS) to demonstrate that sewage sludge obtained from a standardized and controlled manufacturing process can be safely recycled as organic fertilizer. The agronomic and environmental characteristics of the PDSS product were analyzed and compared to other organic fertilizers. Its fertilizing potential was also evaluated through plant growth trials. PDSS was characterized by a high concentration of total $\mathrm{N}(6.6 \% w / w)$, which was all present in organic form. PDSS also showed a low concentration of heavy metals, an absence of pathogens and low concentrations of organic contaminants. Plant growth trials showed that the PDSS was able to improve lettuce and carrot growth $(+25$ and $+46 \%$ of dry weight compared to the unfertilized control), as well as their physiological status. Considering all the results, the exclusion of sewage sludge relying only on its origin and not on its quality appears to conflict with the principles of the circular bioeconomy.
\end{abstract}

Keywords: biomass; organic contaminants; recycle; sludge; wastewater treatment

\section{Introduction}

The world's population continues to grow, with a medium-variant projection indicating that the global population could reach 10 billion in 2050 [1]. Therefore, the need for more food production is evident to feed the world's growing population, as well as to achieve the Sustainable Development Goals, i.e., Zero Hunger, defined by the United Nations in 2015 [2]. With agriculture being the major source of food [3], increasing crop yields represents a priority challenge. In recent decades, agricultural productivity has been enhanced mainly by using fertilizers, and world demand for nitrogen, phosphorus and potassium for fertilizer use is expected to increase by about 10\% from 2016 to 2022 [4]. The increasing requirement for fertilizers poses serious issues related mainly to their production and environmental impact. Indeed, synthetic $\mathrm{N}$ and $\mathrm{P}$ fertilizers are commonly produced from non-renewable resources using high-cost processes [5,6], and environmental issues related to their use are well known (e.g., eutrophication, gaseous emissions) [7]. The use of organic fertilizers has enhanced the sustainability of agricultural production, decreasing the need for non-renewable resources and the environmental impact of agriculture [8]. For instance, it was recently reported that anaerobic digestate can replace urea as a fertilizer in agriculture without increasing ammonia emissions and reduces the risk of soil and water pollution $[9,10]$.

The fertilizer framework in the European Union has been recently reviewed by EU Regulation 1009/2019, which laid down rules and quality requirements for the commercialization of fertilizers [11]. The new regulation aims to increase the circularity of agriculture, 
i.e., by encouraging the recovery of nutrients from secondary sources. EU Regulation 1009/2019 states that, "an EU fertilizing product shall consist solely of component materials complying with the requirements for one or more of the component materials categories (CMCs) listed in Annex 2." Plants or their parts, compost, fresh crop digestate, digestate other than fresh crop digestate, manure and processed manure and food-industry by-products are listed as CMCs. Therefore, they can be used to formulate organic and organo-mineral fertilizers marketable in the EU when they comply with certain requirements, i.e., type of feedstocks, absence of pathogens. Sewage sludge, which is defined as the solid or semisolid residues obtained from the treatment of wastewater [12], are excluded from the list of $\mathrm{CMCs}$ and are not considered as possible fertilizer constituents. The exclusion of sewage sludge from the CMCs list is mainly based on the evidence that certain sewage sludge, i.e., sludge derived from the treatment of municipal wastewaters, is highly contaminated by pathogens, microplastics, heavy metals and organic micropollutants [13-15]. As a consequence, agricultural reuse of municipal sewage sludge may result in environmental threats to the soil such as those recently reported by Rolsky et al., who showed that the application of municipal sewage sludge could introduce microplastics into the soil [15]. Other studies have also reported the accumulation of total and bioavailable heavy metals in soil after repeated municipal sewage sludge application [16]. Nevertheless, not all sewage sludge is produced by the biological treatment of municipal wastewaters: it can also be produced by manufacturing activities (e.g., food, pharmaceutical, chemical and textile industries). For example, about 10 million tonnes (dry matter) of municipal sewage sludge are produced annually in Europe (EU-28) [17], whereas the food industries in Europe generate about 20 million (dry matter) tonnes of sewage sludge [18]. Industrial wastewaters usually result from standardized production processes, and their quality, as well as the quality of the resulting sewage sludge is often higher than that of municipal wastewaters and municipal sewage sludge. For instance, agro-industrial and pharmaceutical sewage sludge have been proven to contain high concentrations of plant nutrients ( $\mathrm{N}, \mathrm{P}$ and $\mathrm{K}$ ) and lower concentrations of heavy metals and pathogens in comparison to municipal sewage sludge $[19,20]$. Cucina et al. have also showed that repeated applications of pharmaceutical sewage sludge on agricultural lands improved soil fertility (i.e., increased organic matter quality and plant nutrients), concluding that agricultural reuse of this sludge may represent a sustainable re-use strategy [21]. In addition, recent literature has pointed out that biomasses commonly used in agriculture and reported as CMCs (e.g., compost and manure) can contain high concentrations of heavy metals and emerging organic pollutants (i.e., pharmaceuticals). Significant concentrations of dioxins and heavy metals were found in compost from green wastes [22], whereas antibiotics were reported to be the major contaminants in processed and unprocessed manures [23]. Therefore, definitions of CMCs, which rely only on the definitions and origins of biomasses may be misleading, since certain sewage sludge might show better agronomic and environmental performance than compost, manures and other secondary sources classified in the CMCs list. The exclusion of all sewage sludge from the CMCs is also in conflict with the principles of the circular bioeconomy and the European Directive 2018/851/EC [24]. The latter provides a waste hierarchy that shall apply as a priority order in waste prevention and management legislation and policy: prevention, reuse, recycling, other recovery and disposal. Excluding all sewage sludge from the fertilizer framework will lead to a depletion of reusable nutrients and increased environmental issues related to their use or disposal, i.e., waste use in agriculture [25], co-composting [26] and landfill $[27,28]$. 
In this context, the aim of the present work was to challenge the origin paradigm of the European Fertilizer Regulation and demonstrate that well characterized sewage sludge might be included in the list of CMCs, moving to a quality paradigm. To achieve this aim, sewage sludge obtained from a standardized manufacturing activity (pharmaceutical industry) was characterized and the analytical results were compared to those of other biomasses currently comprised in the list of CMCs by the European Regulation 1009/2019. The characterization focused on fertilizing properties (contents of plant nutrients and organic matter), the presence of pathogens, heavy metals and emerging organic pollutants. The fertilizing performance was also evaluated using plant growth assays.

\section{Materials and Methods}

\subsection{Production and Collection of the Pharmaceutical Dried Sewage Sludge}

The sewage sludge used in this study was produced in a wastewater treatment facility, which is part of a pharmaceutical plant located in the Lombardy Region (Tribiano, Milano, Lombardy region). The plant produces intermediates of $\beta$-lactam antibiotics.

The schematic representation of both the pharmaceutical plant and the wastewater treatment facility is given in Figure 1. Briefly, raw materials are processed in controlled reactors where the chemical synthesis of the antibiotics' intermediates occurs. After filtration and the recovery of the crystallized products, exhausted solvents and process waters are separated through distillation and processed waters move to the wastewater treatment section. The "equalization" stage allows for a constant composition of the influent that reaches the biological oxidation section. At the end of the oxidation, the effluent is concentrated by using several successive systems (membrane filtration, screw press and air dryer) from an initial concentration of total solids (TS) of $8 \mathrm{~g} \mathrm{~L}^{-1}$ to a final concentration of TS of $95 \% w / w$. Reclaimed waters are discharged to a surface water body or sent again to the biological oxidation unit, whereas exhausted air from the air dryer is forced to pass through a biofilter.

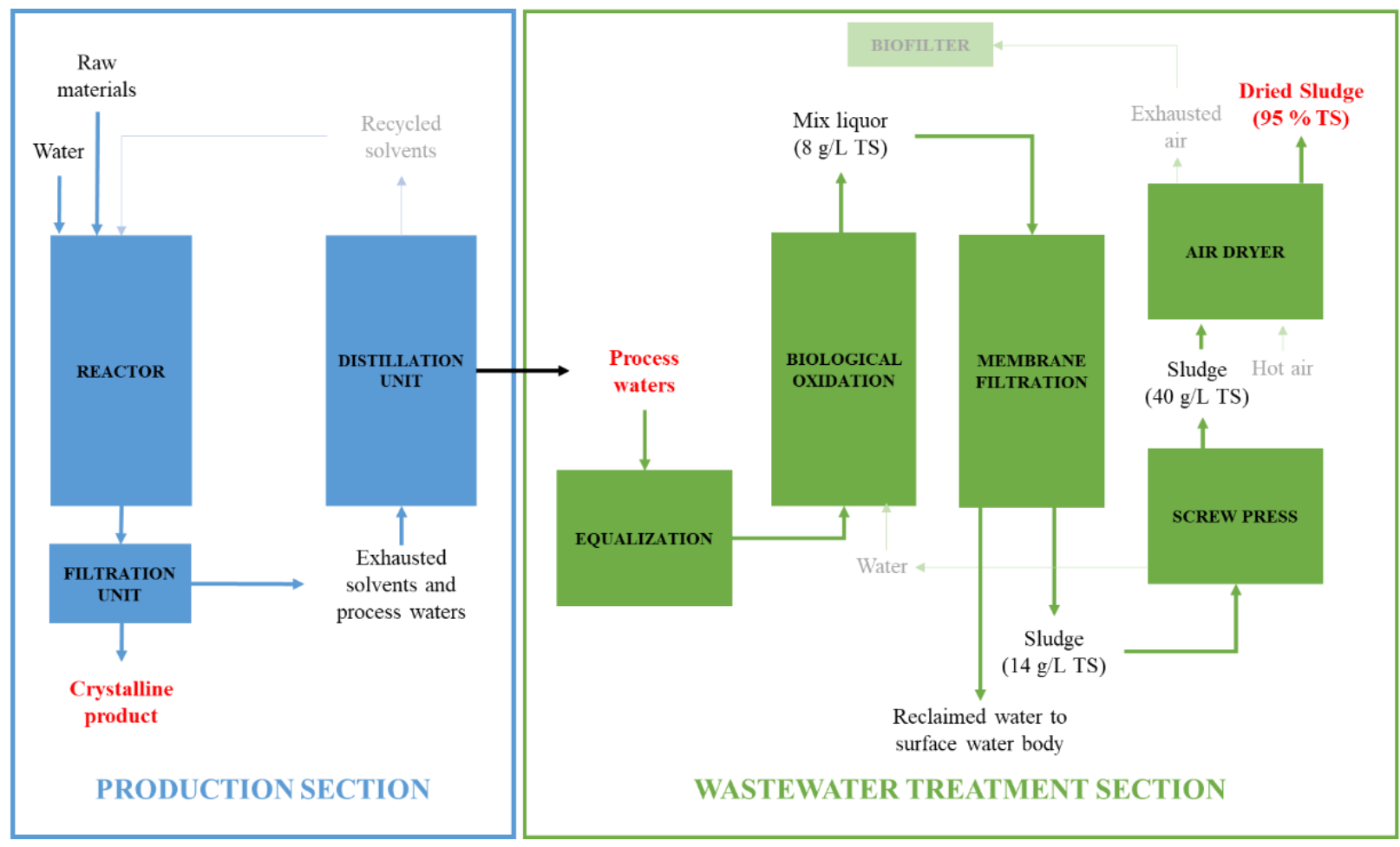

Figure 1. Scheme of the main sections of the pharmaceutical plant. 
The pharmaceutical dried sewage sludge (PDSS) was sampled at the exit of the air dryer four times during a year in order to study composition variability. About $1 \mathrm{~kg}$ of PDSS was collected on each occasion and transferred to the laboratories for analytical determinations and agronomic trials.

In order to compare the agronomic quality of PDSS to an organic $\mathrm{N}$ fertilizer available in the market, dried cattle manure (DCM) [26] was purchased from a local store and sampled for analytical determinations and fertilizing trials.

\subsection{Analytical Methods}

\subsubsection{Physico-Chemical Analysis}

In order to assess the variability of PDSS composition, four samples of PDSS were analyzed during the year. $\mathrm{pH}$, TS and volatile solids (VS) were analyzed following standard procedures [29]. Total organic $\mathrm{C}$ (TOC), total $\mathrm{N}$ and organic $\mathrm{N}$ were determined using official methods for the analysis of organic fertilizers and amendments [30]. Nutrients $(\mathrm{P}$, $\mathrm{K}, \mathrm{Ca}, \mathrm{Mg}$ and $\mathrm{Na}$ ) were determined by inductively coupled plasma mass spectrometry (Varian, Fort Collins, CO, USA) preceded by acid digestion [31].

\subsubsection{Heavy Metals, Pathogens and Organic Contaminants}

Heavy metals were determined by inductively coupled plasma mass spectrometry (Varian, Fort Collins, CO, USA) preceded by acid digestion [31]. In addition to heavy metals analysis prescribed by European and Italian regulations concerning fertilizer quality $(\mathrm{Pb}, \mathrm{Cu}, \mathrm{Zn}, \mathrm{Ni}, \mathrm{Cd}, \mathrm{Hg}, \mathrm{Cr} \mathrm{VI}, \mathrm{As})$, total $\mathrm{Cr}$, Be and Se were also analyzed as suggested by the recent literature [9,32].

Pathogens (Salmonella spp., fecal coliform and Escherichia coli) were determined according to standard procedures [33].

Organic contaminants (hydrocarbons, PAHs, PCDD/PCDF, PCB and toluene) were analyzed following standard methods [34-39]. Residues of (6R-trans)-7-amino-3-[[(5-methyl1,3,4-thiadiazol-2-yl)thio]methyl]-8-oxo-5-thia-1-azabicyclo[4,2,0]oct-2-ene-2-carboxylic acid (7-ZACA) were analyzed since this molecule is the intermediate produced throughout the year at the pharmaceutical plant where the PDSS was sampled. 7-ZACA residues were analyzed through high performance liquid chromatography coupled to mass spectrometry (HPLC-MS).

\subsection{Plant Growth Trials}

\subsubsection{Experimental Design}

The fertilizing properties of PDSS were assessed through plant growth assays using dried cattle manure (DCM) as the organic reference material and unfertilized soil as a control in the test (CONTROL). Soil characteristics before and after fertilization are reported in Table 1. The water-holding capacity of the soil was determined according to standard procedures [40]. Lettuce (Lactuca sativa L., variety Derby) and carrots (Daucus carota L., variety Soprano) were selected as test species since they are commonly used in fourth-range production. Fourth-range vegetables may represent a suitable market for PDSS in replacing synthetic fertilizers due to the large incomes of the sector. In addition, selecting lettuce and carrots allowed evaluating the fertilizing effects on both hypogea (roots) and apogee (leaves) producing crops.

PDSS and DCM were dosed in order to apply $150 \mathrm{~kg} \mathrm{~N} \mathrm{ha}^{-1}$ and $195 \mathrm{~kg} \mathrm{~N} \mathrm{ha}^{-1}$ for lettuce and carrots, respectively, according to plant requests. DCM was used as a reference material because it contains organic N such as PDSS, and it is routinely used as an organic-commercial fertilizer to produce horticultural crops. To do so, the same amount of total $\mathrm{N}$ was dosed for both PDSS and DCM.

Plastic jars ( $3 \mathrm{~L}$ volume, provided with holes in the bottom) were filled with $2.5 \mathrm{~kg}$ of soil and organic fertilizers were applied on the top of the soil and mixed with it. After two days, lettuce and carrot plants (one for each vessel) were transplanted into unfertilized and fertilized jars. Each treatment was replicated four times for a total of 24 jars ( 3 treatments 
$\times 2$ species $\times 4$ replicates). During the fertilizing assays, water was periodically added to all jars in order to maintain the soil at $75 \%$ of its water-holding capacity $\left(22.5 \mathrm{~g} 100 \mathrm{~g}^{-1}\right.$ soil dry matter). Weeds were manually removed periodically.

Table 1. Main characteristics of the soils, pharmaceutical dried sewage sludge and dried cattle manure used in the experiments.

\begin{tabular}{|c|c|c|c|c|c|c|}
\hline Parameter & Unit $^{a}$ & Soil & PDSS $^{b}$ & Soil + PDSS & $\operatorname{DCM}^{c}$ & Soil + DCM \\
\hline $\mathrm{pH}$ & - & $6.0^{\mathrm{d}} \pm 0.1$ & $8.0 \pm 0.1$ & $6.1 \pm 0.1$ & $7.2 \pm 0.1$ & $6.0 \pm 0.2$ \\
\hline Total solids & $\%$ & n.d. ${ }^{\mathrm{e}}$ & $96.1 \pm 1.0$ & n.d. & $52.3 \pm 1.0$ & n.d. \\
\hline Total organic C & $\%$ & $1.5 \pm 0.1$ & $35.5 \pm 1.2$ & $1.6 \pm 0.1$ & $41.2 \pm 1.7$ & $1.4 \pm 0.2$ \\
\hline Total N & $\%$ & $0.18 \pm 0.01$ & $6.6 \pm 0.2$ & $0.22 \pm 0.00$ & $4.2 \pm 0.4$ & $0.21 \pm 0.01$ \\
\hline Organic N/Total N & $\%$ & n.d. & 100 & n.d. & $82.3 \pm 0.2$ & n.d. \\
\hline $\mathrm{C} / \mathrm{N}$ & - & $8.3 \pm 0.7$ & $5.4 \pm 0.4$ & $7.3 \pm 0.1$ & $9.8 \pm 0.1$ & $6.7 \pm 0.2$ \\
\hline Total P & $\%$ & n.d. & $0.6 \pm 0.1$ & n.d. & $1.1 \pm 0.2$ & n.d. \\
\hline Total P & $\mathrm{Mg} \mathrm{P}_{2} \mathrm{O}_{5} \mathrm{~kg}^{-1}$ & $109 \pm 5$ & n.d. & $106 \pm 8$ & n.d. & $110 \pm 4$ \\
\hline Total K & $\%$ & $2.1 \pm 0.0$ & $0.4 \pm 0.1$ & $2.1 \pm 0.1$ & $3.0 \pm 0.3$ & $2.3 \pm 0.1$ \\
\hline Total Ca & $\%$ & n.d. & $4.6 \pm 0.2$ & n.d. & $1.4 \pm 0.0$ & n.d. \\
\hline Total Mg & $\%$ & n.d. & $0.2 \pm 0.1$ & n.d. & $0.6 \pm 0.1$ & n.d. \\
\hline Total Na & $\%$ & n.d. & $1.1 \pm 0.1$ & n.d. & $1.3 \pm 0.1$ & n.d. \\
\hline Water-holding capacity & $\%$ & $30 \pm 1$ & n.a. ${ }^{f}$ & n.d. & n.a. & n.d. \\
\hline Cation exchange capacity & $\mathrm{cmol} \mathrm{kg}^{-1}$ & $18.6 \pm 1.3$ & n.a. & n.d. & n.a. & n.d. \\
\hline
\end{tabular}

${ }^{a}$ Results expressed on dry weight basis, except for $\mathrm{pH}$ and total solids. ${ }^{\mathrm{b}}$ Pharmaceutical dried sewage sludge. ${ }^{\mathrm{c}}$ Dried cattle manure.

${ }^{\mathrm{d}}$ Mean value $\pm \mathrm{SD}, n=4 .{ }^{\mathrm{e}}$ Not determined. ${ }^{\mathrm{f}}$ Not applicable.

\subsubsection{Physiological Status and Plant Yields}

The chlorophyll content (CHL), epidermal UV-absorbance (FLAV) and Nitrogen Balance Index (NBI) were analyzed on lettuce leaves (5 leaves per plant) using a Dualex ${ }^{\circledR}$ scientific leaf clip (ForceA, Orsay, France) at day 20, whereas the carrot leaves did not allow for this method to be used. Lettuce plants were harvested after 28 days from the beginning of the fertilizing assay, while carrot plants were harvested after 48 days. Lettuce roots were removed and the fresh weight of the green plant was recorded. The fresh weight was also determined for carrot plants after cleaning them from soil residues. The dry weight of the plants was determined by drying them in a ventilated oven at $50 \pm 2{ }^{\circ} \mathrm{C}$ until a constant weight was reached. $\mathrm{N}$ concentration in lettuce and carrot plants was determined through an $\mathrm{N}$-analyzer (Elementar Analysensysteme $\mathrm{GmbH}$, Langenselbold, Germany) whereas $\mathrm{P}$ and $\mathrm{K}$ concentrations were determined by inductively coupled plasma mass spectrometry (Varian, Fort Collins, CO, USA) preceded by acid digestion [31].

\subsubsection{Leachate Collection and Characterization}

Leachate analysis was carried out in order to evaluate the potential for groundwater contamination consequent to PDSS and DCM application to the soil. Leachates from all the jars were obtained after 20 days from the beginning of the agronomic trials by adding water to allow leaching from the bottom of the plastic jars ( $100 \mathrm{~mL}$ of water for each jar). Leachate samples were collected and immediately filtered through a $0.45 \mu \mathrm{m}$ syringe filter. $\mathrm{pH}$ and electrical conductivity were determined following standard procedures [29], while $\mathrm{NH}_{4}{ }^{+}-\mathrm{N}$ and $\mathrm{NO}_{3}{ }^{-}-\mathrm{N}$ were evaluated using spectrophotometric methods (Ammonium 10 and Nitrat 50 detection kit, Nanocolor, Macherey-Nagel, Düren, Germany; Compact photometer PF-12, Macherey-Nagel, Düren, Germany). Heavy metals in the leachate samples were determined by inductively coupled plasma mass spectrometry (Varian, Fort Collins, CO, USA) after the acidification of the samples ( $500 \mu \mathrm{L}$ of $\mathrm{HNO}_{3} 69 \% w / v$ in $5 \mathrm{~mL}$ of the sample). 


\subsection{Statistics}

The reported results were the average values of three analytical replicates, and standard deviation was calculated using standard procedures. The determination of significant differences among the parameters analyzed at a level of significance of $p<0.05$ was carried out by a two-way analysis of variance (ANOVA) and Tukey's test (Microsoft Excel Solver 2013).

\section{Results and Discussion}

\subsection{Characterization of the Dried Pharmaceutical Sewage Sludge and Agronomic Value}

The fertilizing potential of biomasses depends mainly on their physico-chemical characteristics and nutrients concentration, which depend on feedstock characteristics and the operational parameters of the process by which they were produced. The main characteristics of PDSS are reported in Table 1 and compared to DCM, in order to assess its agronomic value.

PDSS was characterized by a sub-alkaline $\mathrm{pH}$ and a high content of TS (8.0 and $96.1 \%$ $w / w$, respectively). The reduced content of water may represent an advantage for the management of the PDSS due to the reduction in the transport and distribution costs in comparison with liquid fertilizers [41]. Nevertheless, energy consumption for PDSS drying and dusting in using PDSS as fertilizer can represent possible problems. The sub-alkaline $\mathrm{pH}$ is typical of sewage sludge, mature compost and manures, and it was related to the presence of basic cations ( $\mathrm{Ca}$ and $\mathrm{Na}$ ). This can have a positive mineral alkalizing effect on soil, at least in the short-term [19]. The sludge showed a high concentration of TOC and total $\mathrm{N}(35.5$ and $6.6 \% w / w)$, with the $\mathrm{N}$ represented by only organic $\mathrm{N}$ (organic $\mathrm{N} /$ total $\mathrm{N}$ ratio was $100 \%)$.

These results make the PDSS potentially classifiable as an $\mathrm{N}$ organic fertilizer under the Italian fertilizer regulation [26]. The presence of $\mathrm{N}$ in the organic form is typical of $\mathrm{N}$ organic fertilizers, i.e., DCM, and represents a positive characteristic since organic $\mathrm{N}$ is slowly mineralized by microorganisms in soil, representing a long-term source of this element for the crops. The low $\mathrm{C} / \mathrm{N}$ value of PDSS (5.4) ensured that the $\mathrm{N}$ immobilization process after land application should not occur [42].

The other macronutrients studied ( $\mathrm{P}$ and $\mathrm{K}$ ) were detected in PDSS in concentrations lower than that of $\mathrm{N}(0.6$ and $0.4 \% w / w$, respectively). These values were lower than $\mathrm{P}$ and $\mathrm{K}$ concentrations commonly found in DCM and other organic fertilizers (i.e., manure, digestate and composts) (Table 1) [19,43], but still represent a valuable content of recoverable nutrients. With respect to the other elements analyzed, their concentrations decreased following the order $\mathrm{Ca}>\mathrm{Na}>\mathrm{Mg}$ and the values measured did not differ significantly from those of the DCM and other biomasses described in the literature $[9,19,44]$.

Summarizing, the analyzed PDSS showed a high concentration of organic matter and $\mathrm{N}$ in organic form that confirm its high agronomic value. The comparison of PDSS to a marketable $\mathrm{N}$ organic fertilizer (DCM) and to other biomasses showed that the analyzed sewage sludge might be considered as a potential $\mathrm{N}$ organic fertilizer. It should be also highlighted that the composition of PDSS showed a high homogeneity throughout the year, as demonstrated by the low SD values determined. This was expected since the sludge was obtained from a standardized production process.

\subsection{Environmental Aspects}

Besides the chemical composition, a complete assessment of a new fertilizer should also evaluate the environmental aspects. In this paper, heavy metals, pathogens and organic contaminants were analyzed in the PDSS and the results were compared to the DCM and other biomasses commonly used as fertilizers and reported in the following paragraphs. 


\subsubsection{Heavy Metals}

Results of the heavy metal determination are reported in Table 2. Cd, Cr VI, and Be were under the detection limit of the method used in all the PDSS samples analyzed. The other heavy metals analyzed were all present in low concentrations in PDSS and the highest concentration was observed for $\mathrm{Zn}\left(79 \mathrm{mg} \mathrm{kg}^{-1}\right)$. With the exception of total $\mathrm{Cr}$, all the heavy metals were detected in PDSS at concentrations lower than those measured in the DCM. Although total $\mathrm{Cr}$ was the second heavy metal in PDSS in terms of concentration, it was always much lower than that found for other organic amendments (e.g., compost) (Table 2). Moreover, $\mathrm{Cr}$ VI (the toxic form of $\mathrm{Cr}$ ) was always found under the detection limit of the method and under the limits established by European and Italian Regulations [11,26]. The low concentration of heavy metals in PDSS was expected since all the raw materials used in the pharmaceutical productive process are certified for their quality (i.e., absence of heavy metals). Interestingly, PDSS was characterized by a lower concentration of heavy metals than other sewage sludge (i.e., agro-industrial and municipal sewage sludge, Table 2) and this was particularly evident for $\mathrm{Zn}, \mathrm{Cu}, \mathrm{Cd}, \mathrm{Pb}$ and Ni. The same conclusions were obtained from the comparison of the PDSS and other biomasses that are commonly used in agriculture (i.e., composts and digestates) that showed higher contents of heavy metals in comparison with the sewage sludge analyzed in this work. For instance, $\mathrm{Pb}$ concentration in composts can be ten times higher than the concentration detected in PDSS (24 and $12.4 \mathrm{mg} \mathrm{kg}^{-1}$ for green compost and organic waste compost versus $1.3 \mathrm{mg} \mathrm{kg}^{-1}$ in PDSS). Similarly, $\mathrm{Zn}$ and $\mathrm{Cu}$ contents in anaerobically digested sewage sludge were found to be thirty and ten times higher, respectively, than the contents in PDSS. Moreover, when the comparison was carried out between the PDSS and the straw described in Scaglia et al. it emerged that the two materials did not differ significantly [22].

All the heavy metals analyzed in the PDSS were largely under the limits established by both the Italian and EU regulations for fertilizer production and commercialization [11,26]. Conversely, some of the biomasses used for the comparison exceeded the limits (e.g., digestates), demonstrating that sewage sludge produced from a standardized process can represent a safer source of nutrients in terms of heavy metal content compared with biomasses recognized as CMCs. In addition, the low concentrations of heavy metals in PDSS and the low application dose used for $\mathrm{N}$ fertilizers make the accumulation and bioabsorption of heavy metals in soil unlikely after fertilization. Conversely, the accumulation and bio-absorption of heavy metals following the application of compost (i.e., compost from municipal sewage sludge) was reported due to both a high concentration of heavy metals in the biomass and the high amount of materials applied to the soil [45]. 
Table 2. Mean concentration of heavy metals in the pharmaceutical dried sewage sludge and comparison with other biomasses used in agriculture.

\begin{tabular}{|c|c|c|c|c|c|c|c|c|c|c|c|c|}
\hline Parameter & Unit $^{a}$ & PDSS $^{\mathbf{b}}$ & $\mathbf{D C M}^{\mathbf{b}}$ & AISS $^{c}$ & MSS $^{c}$ & $\mathrm{GC}^{\mathrm{d}}$ & OWC $^{d}$ & Straw ${ }^{d}$ & $E{ }^{d}$ & MSSD $^{\text {e }}$ & $\begin{array}{c}\text { Limit } \\
\text { Value }\end{array}$ & $\begin{array}{c}\text { Limit } \\
\text { Value } \mathrm{g}\end{array}$ \\
\hline $\mathrm{Pb}$ & $\mathrm{mg} \mathrm{kg}^{-1}$ & $1.3 \pm 0.5^{h}$ & $5.0 \pm 0.4$ & $52.2 \pm 3.7$ & $<5.6$ & $24 \pm 0.2$ & $12.4 \pm 1.0$ & $3.2 \pm 0.1$ & $3.0 \pm 0.0$ & $64 \pm 11$ & 140 & 120 \\
\hline $\mathrm{Cu}$ & $\mathrm{mg} \mathrm{kg}^{-1}$ & $13.0 \pm 5.6$ & $58.3 \pm 1.8$ & $30.6 \pm 1.3$ & $140.8 \pm 2.4$ & $53.5 \pm 1.6$ & $37.6 \pm 1.5$ & $18.3 \pm 1.2$ & $83.3 \pm 1.1$ & $408 \pm 60$ & 230 & 300 \\
\hline $\mathrm{Zn}$ & $\mathrm{mg} \mathrm{kg}^{-1}$ & $79 \pm 16$ & $179 \pm 8$ & $84 \pm 3$ & $757 \pm 12$ & $151 \pm 3$ & $106 \pm 3$ & $54 \pm 2$ & $393 \pm 4$ & $1020 \pm 120$ & 500 & 800 \\
\hline $\mathrm{Ni}$ & $\mathrm{mg} \mathrm{kg}^{-1}$ & $8.6 \pm 1.9$ & $6.1 \pm 0.2$ & $44.3 \pm 3.1$ & $22.6 \pm 0.9$ & $41.8 \pm 1.0$ & $7.1 \pm 1.0$ & $4.4 \pm 0.6$ & $9.6 \pm 0.5$ & $61.0 \pm 13.0$ & 100 & 50 \\
\hline $\mathrm{Cd}$ & $\mathrm{mg} \mathrm{kg}^{-1}$ & $<0.1^{\mathrm{i}}$ & $<0.1$ & $4.6 \pm 0.2$ & $1.0 \pm 0.1$ & $0.17 \pm 0.03$ & $0.33 \pm 0.09$ & $0.12 \pm 0.02$ & $0.37 \pm 0.05$ & $1 \pm 0.5$ & 1.5 & 1.5 \\
\hline $\mathrm{Hg}$ & $\mathrm{mg} \mathrm{kg}^{-1}$ & $0.6 \pm 0.2$ & $0.4 \pm 0.0$ & $<0.2$ & $<1.3$ & $0.8 \pm 0.0$ & $0.1 \pm 0.0$ & $0.4 \pm 0.0$ & $0.2 \pm 0.1$ & $0.1 \pm 0.3$ & 1.5 & 1 \\
\hline Cr VI & $\mathrm{mg} \mathrm{kg}^{-1}$ & $<0.2$ & $<0.2$ & - & - & $<0.2$ & $<0.2$ & $<0.2$ & $<0.2$ & - & 0.5 & 2 \\
\hline As & $\mathrm{mg} \mathrm{kg}^{-1}$ & $0.9 \pm 0.2$ & $1.1 \pm 0.1$ & - & - & $0.5 \pm 0.1$ & $0.6 \pm 0.1$ & $0.2 \pm 0.0$ & $1.1 \pm 0.2$ & $9.0 \pm 2.2$ & - & 40 \\
\hline Se & $\mathrm{mg} \mathrm{kg}^{-1}$ & $0.2 \pm 0.1$ & $0.6 \pm 0.1$ & - & - & - & - & - & - & $3.7 \pm 2.1$ & - & - \\
\hline $\mathrm{Be}$ & $\mathrm{mg} \mathrm{kg}^{-1}$ & $<0.5$ & $<0.5$ & - & - & - & - & - & - & - & - & - \\
\hline
\end{tabular}

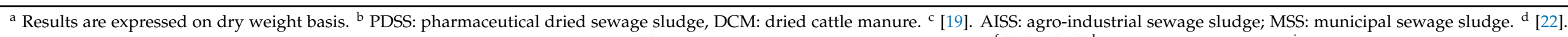

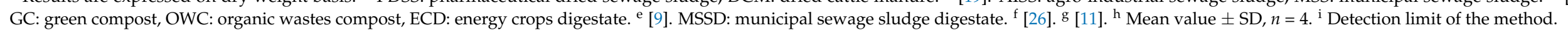




\subsubsection{Pathogens}

Mean concentrations of pathogens in the PDSS and the comparison of the results with those of other biomasses commonly used in agriculture are reported in Table 3. All the pathogens analyzed (Salmonella spp., fecal coliform and Escherichia coli) were absent or under the detection limit of the method used in all the samples of PDSS. This was probably due to the high air temperature used during the drying process of the pharmaceutical sewage sludge and the results were in accordance with Romdhana et al. who reported that various heating technologies were effective to reduce pathogens in sewage sludge [46].

Table 3. Mean concentration of pathogens in the pharmaceutical dried sewage sludge and comparison with other biomasses used in agriculture.

\begin{tabular}{cccc}
\hline & Salmonella spp. & Faecal Coliform & Escherichia coli \\
\hline Unit $^{\mathrm{a}}$ & Presence-absence in $25 \mathrm{~g}$ & $\mathrm{CFU}^{\mathrm{b}} \mathrm{g}^{-1}$ & $\mathrm{CFU} \mathrm{g}^{-1}$ \\
PDSS & Absent & $<10^{\mathrm{c}}$ & $<10$ \\
DCM & Absent & $<10$ & $<10$ \\
AISS & Absent & - & $<10$ \\
MSS $^{\mathrm{d}}$ & Absent & - & $8.9 \times 10^{2}$ \\
GC $^{\mathrm{e}}$ & Absent & $7 \times 10^{4} \pm 3.6 \times 10^{2}$ & $1 \times 10^{2} \pm 0.4 \times 10^{2}$ \\
OWC $^{\mathrm{e}}$ & Absent & $0 \pm 0$ & $0 \pm 0$ \\
ECD $^{\mathrm{e}}$ & Absent & $0 \pm 0$ & $0 \pm 0$ \\
MSSD $^{\mathrm{f}}$ & Absent & - & Absent \\
Straw $^{\mathrm{e}}$ & Absent & $0 \pm 0$ & $0 \pm 0$ \\
Limit value $^{\mathrm{g}}$ & Absent in $25 \mathrm{~g}$ & - & - \\
Limit value $^{\mathrm{h}}$ & Absent in $25 \mathrm{~g}$ & - & $10^{3} \mathrm{~g}^{-1}$ \\
\hline
\end{tabular}

a Results are expressed on a dry weight basis. ${ }^{b}$ Colony forming unit. ${ }^{c}$ Detection limit of the method. ${ }^{d}$ [19] AISS: agro-industrial sewage sludge; MSS: municipal sewage sludge. ${ }^{\mathrm{e}}$ [22]. GC: green compost, OWC: organic wastes compost, ECD: energy crops digestate. ${ }^{\mathrm{f}}$ [9]. MSSD: municipal sewage sludge digestate. ${ }^{\mathrm{g}}$ [26]. ${ }^{\mathrm{h}}$ [11].

As a consequence, the PDSS complied with the limits established by both Italian and European regulations concerning fertilizers with regard to pathogens content $[11,26]$.

Pathogens were also absent in the DCM as the result of the aerobic maturation and drying which DCM undergoes before its commercialization [47].

The high hygiene quality of PDSS appeared to be ensured by two factors. First, the wastewater facility treats only the process waters from the manufacturing activities and thus it should not contain pathogens. In addition, the drying process ensured the destruction of pathogens that can contaminate the wastewater treatment section. Consequently, pathogen contamination of PDSS appears to be unlikely, in contrast with municipal sewage sludge (Table 3) [19]. Pathogens may also contaminate other biomasses classified as CMCs, especially when the production process is not carried out in optimal conditions. For instance, pathogens can survive during composting if the materials do not reach a sufficiently high temperature during the active phase of the process, leading to the production of composts that do not comply with pathogens limits [22,48].

\subsubsection{Organic Contaminants}

With regard to organic pollutants, it was decided to analyze the concentration of organic pollutants on which the attention of the scientific literature is focused for the agricultural use of biomasses, e.g., hydrocarbons, polycyclic aromatic hydrocarbons (PAH), dioxins and furans, polychlorinated biphenyl (PCB) and toluene $[9,22,23]$. In addition, 7-ZACA residues were determined since this was the main intermediate produced at the pharmaceutical facility that produced the studied sewage sludge. Results of the determination of organic contaminants are reported in Table 4. 
Table 4. Mean concentration of emerging organic contaminants in the pharmaceutical dried sewage sludge and comparison with other biomasses used in agriculture.

\begin{tabular}{|c|c|c|c|c|c|c|c|c|c|c|}
\hline Parameter & Unit & PDSS $^{\mathrm{a}}$ & $\mathrm{DCM}^{\mathrm{a}}$ & AISS $^{b}$ & MSS $^{b}$ & $\mathrm{GC}^{\mathrm{c}}$ & OWC $^{c}$ & $\mathrm{ECD}^{\mathrm{c}}$ & MSSD $^{d}$ & Straw $^{c}$ \\
\hline Hydrocarbons $(\mathrm{C}<12)$ & $\mathrm{mg} \mathrm{kg}^{-1}$ f.w. & $21 \pm 8^{\mathrm{e}}$ & $35 \pm 2$ & - & - & - & - & - & - & - \\
\hline Hydrocarbons $(C>12)$ & $\mathrm{mg} \mathrm{kg}^{-1}$ f.w. & $697 \pm 337$ & $1120 \pm 142$ & - & - & - & - & - & - & - \\
\hline Total hydrocarbons & $\mathrm{mg} \mathrm{kg}^{-1}$ f.w. & $613 \pm 380$ & $1155 \pm 99$ & - & - & - & - & - & $284 \pm 251$ & - \\
\hline PCDD/PCDF + PCB DL & ngWHO-TEQ $\mathrm{kg}^{-1}$ d.m. & $0.3 \pm 0.0$ & $<0.1$ & 5.3 & 4.8 & 1.0 & 0.3 & 0.9 & $10.6 \pm 2.9$ & 0.2 \\
\hline PCB & $\mathrm{mg} \mathrm{kg}^{-1} \mathrm{~d} . \mathrm{m}$ & $<0.1$ & $<0.1$ & $<$ d.l.m. & $<$ d.l.m. & 0.01 & 0.02 & 0.12 & $<0.1$ & 0.00 \\
\hline Toluene & $\mathrm{mg} \mathrm{kg}^{-1}$ d.m. & $<10$ & $<10$ & - & - & - & - & - & - & - \\
\hline 7-ZACA & $\mathrm{mg} \mathrm{kg}^{-1}$ d.m. & $<0.01$ & - & - & - & - & - & - & - & - \\
\hline
\end{tabular}

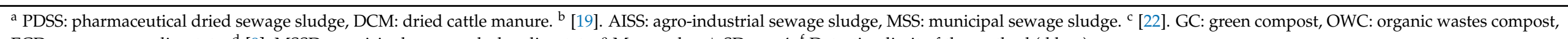
ECD: energy crops digestate. ${ }^{\mathrm{d}}$ [9]. MSSD: municipal sewage sludge digestate. ${ }^{\mathrm{e}}$ Mean value $\pm \mathrm{SD}, n=4 .{ }^{\mathrm{f}}$ Detection limit of the method (d.l.m.). 
PAH, PCB and toluene concentrations were under the detection limit in all the PDSS samples analyzed, as well as in DCM. Dioxins and furans were found in PDSS at low concentrations $\left(0.3 \mathrm{ng} \mathrm{kg}^{-1}\right)$ and this value was lower than that of dioxin and furan concentrations found in agro-industrial and municipal sewage sludge, composts and digestates $[9,19,22]$. The total hydrocarbon content in PDSS was not significantly different from the value observed in DCM and the presence of these compounds was attributed to the biological activity of microorganisms rather than to external contamination [49]. In addition, the total hydrocarbon content in the PDSS $\left(613 \mathrm{mg} \mathrm{kg}^{-1}\right)$ was significantly lower than the hydrocarbon content reported from ARPAV for seventeen digestates obtained from the anaerobic digestion of livestock manure and organic wastes [50]. For instance, the content of total hydrocarbons ranged from 720 to $4600 \mathrm{mg} \mathrm{kg}^{-1}$ in these digestates and reached the maximum value of $31,800 \mathrm{mg} \mathrm{kg}^{-1}$ in a digestate obtained from the processing of slaughterhouse wastes.

Analysis of 7-ZACA residues in the samples of PDSS showed that in all the samples the concentration of this compound was under the detection limit of the method used $\left(10 \mu \mathrm{g} \mathrm{kg}^{-1}\right)$. In the last decade, issues related to antibiotic contamination of biomasses used in agriculture (i.e., manure, compost and digestate) were pointed out due to their possible negative effects, e.g., the selection of antimicrobial resistant bacteria in soil [23,51].

In this context, the absence of detectable residues of 7-ZACA in the PDSS allows us to affirm that its agricultural use should not represent a threat to soil from this point of view. Conversely, Congilosi and Aga have reported high concentrations of different antibiotics (i.e., macrolides, tetracyclines and sulphonamides) in pig, cattle and chicken manure, which are biomasses admitted to agricultural reuse [23]. For instance, they showed that pig slurry contained $1600-354,000$ and $15-20,000 \mu \mathrm{g} \mathrm{kg}^{-1}$ of macrolides antibiotics, tetracyclines and sulphonamides, respectively [23].

\subsection{Agronomic Trials}

3.3.1. Yields, Physiological Status and the Composition of the Plants

Agronomic trials using lettuce and carrots were carried out to evaluate the fertilizing properties of PDSS in comparison to DCM. The productive results and the physiological status of the lettuce plants before the harvesting are reported in Table 5.

Table 5. Productive and physiological parameters of the plants growth in unfertilized (control) and fertilized soils.

\begin{tabular}{|c|c|c|c|c|c|c|}
\hline & Parameter & Plant & Unit & Control & PDSS $^{a}$ & $\operatorname{DCM}^{\mathbf{b}}$ \\
\hline \multirow{4}{*}{$\begin{array}{l}\text { Productive } \\
\text { parameters }\end{array}$} & \multirow{2}{*}{ Fresh weight } & Lettuce & $\mathrm{g}$ & $53.5^{\mathrm{c}} \pm 4.3 \mathrm{a}$ & $70.0 \pm 3.2 b$ & $71.5 \pm 3.0 \mathrm{~b}$ \\
\hline & & Carrot & $\begin{array}{l}0 \\
\mathrm{~g}\end{array}$ & $40.5 \pm 4.7 \mathrm{a}$ & $56.2 \pm 2.1 \mathrm{~b}$ & $45.6 \pm 6.4 \mathrm{a}$ \\
\hline & \multirow{2}{*}{ Dry weight } & Lettuce & $\mathrm{g}$ & $7.3 \pm 0.6 \mathrm{a}$ & $9.1 \pm 0.2 b$ & $9.3 \pm 0.3 b$ \\
\hline & & Carrot & $\begin{array}{l}0 \\
\mathrm{~g}\end{array}$ & $5.8 \pm 0.9 \mathrm{a}$ & $8.5 \pm 0.5 b$ & $7.1 \pm 1.0 \mathrm{a}$ \\
\hline \multirow{3}{*}{$\begin{array}{c}\text { Physiological } \\
\text { parameters }\end{array}$} & $\mathrm{NBI}^{\mathrm{d}}$ & & - & $13.6 \pm 0.6 \mathrm{a}$ & $17.4 \pm 0.4 \mathrm{~b}$ & $17.5 \pm 0.8 b$ \\
\hline & $\mathrm{CHL}^{\mathrm{e}}$ & Lettuce & - & $25.0 \pm 0.3 \mathrm{a}$ & $29.2 \pm 0.6 \mathrm{~b}$ & $28.1 \pm 0.2 b$ \\
\hline & FLAV $^{\mathrm{f}}$ & & - & $2.0 \pm 0.2$ & $1.6 \pm 0.2$ & $1.6 \pm 0.1$ \\
\hline
\end{tabular}

${ }^{a}$ Pharmaceutical dried sewage sludge. ${ }^{b}$ Dried cattle manure. ${ }^{\mathrm{c}}$ Mean value $\pm \mathrm{SD}, n=4 .{ }^{\mathrm{d}} \mathrm{N}$ balance index. ${ }^{\mathrm{e}}$ Chlorophyll index.

${ }^{\mathrm{f}}$ Flavonoids. Means in the same row followed by different letters are different at $p<0.05$. Means in the same row followed by different letters $(\mathrm{a}, \mathrm{b})$ are different at $p<0.05$.

Fresh and dry weights of lettuce and carrot plants were significantly higher in the trials fertilized with PDSS with respect to the control. Specifically, the dry weight of plants increased by about $25 \%$ and $46 \%$ for lettuce and carrots, respectively. The results obtained with PDSS were not significantly different from the results obtained in the trials fertilized with DCM using lettuce, whereas PDSS fertilization showed better results than DCM when tested on carrots. In fact, the dry weight of carrot plants was $8.5 \mathrm{~g}$ and $7.1 \mathrm{~g}$ in the PDSS and DCM fertilized trials, respectively. Yield increases in the PDSS fertilized trials might be attributed to an improvement in the soil conditions, the supply of additional $\mathrm{N}$, other nutrients and C from the sludge [52]. Results of the agronomic trials carried out in the 
present work confirmed the fertilizing potential of sewage sludge, which generally resulted in higher crop yields in adequately sludge-amended soil when compared with controls fertilized with mineral fertilizers [53].

Not only did the yield of lettuce increase due to PDSS fertilization, but also the physiological status of lettuce plants after 20 days of growth was enhanced (Table 5). CHL and NBI were significantly higher in the lettuce plants grown on PDSS fertilized soil with respect to the control $(+28 \%$ and $+18 \%$, respectively) and similar results were obtained for the plants grown on DCM fertilized soils. With respect to FLAV, no significant differences were observed among the trials. The chlorophyll and phenolic compound content (CHL and FLAV, respectively) provides information on the physiological status of the plants. The results shown in Table 5 highlight that fertilization with PDSS positively affected the physiological status of lettuce and this might be due to the high supply of $\mathrm{N}$ provided by PDSS. In fact, in optimal conditions, plant photosynthesis produces proteins and chlorophyll through primary metabolism; however, in the case of an $\mathrm{N}$ deficiency, plants activate their secondary metabolism that is associated with the production of secondary compounds i.e., flavonoids [54]. Since the NBI is the ratio between CHL and FLV, it is an indicator of the N status of plants and increased values of NBI such as those observed in PDSS fertilized trials confirmed the positive effect of the sewage sludge on plant growth [54].

The composition of the plants grown on PDSS and DCM fertilized soils in comparison to those grown on the unfertilized control soil is shown in Figure 2.

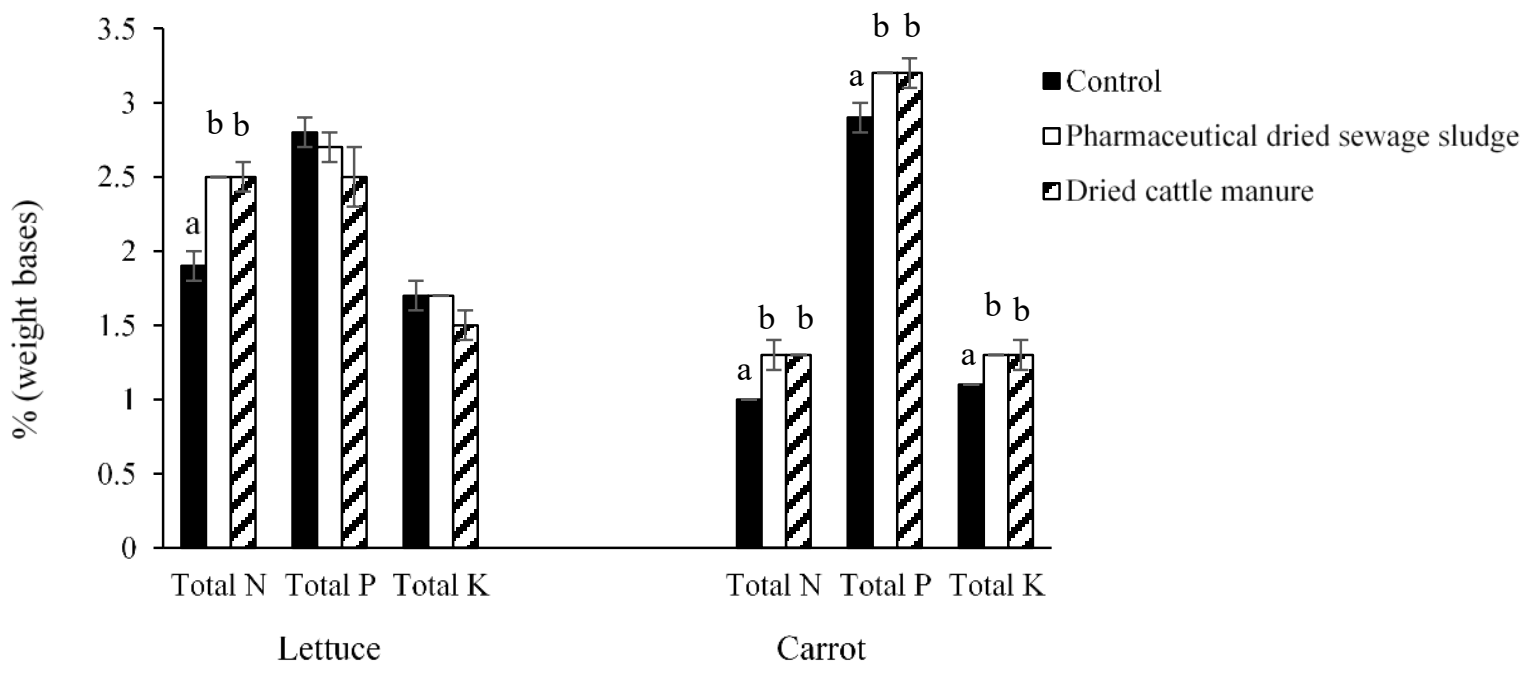

Figure 2. Composition of the plants grown on unfertilized (control) and fertilized soils. Different letters (a, b) indicate that the values are different at $p<0.05$.

Total $\mathrm{N}$ concentration was higher in the lettuce plants growth on fertilized soils (both PSDD and DCM fertilization) with respect to the control (+30\% for both fertilizers). Conversely, neither total P nor total K concentration in lettuce showed differences among the treatments studied. Interestingly, the concentration of all the elements studied $(\mathrm{N}, \mathrm{P}$ and K) was increased in carrots grown on PDSS fertilized soil, with respect to the control trial, and the same results were obtained for carrot plants grown on DCM fertilized soil. The accumulation pattern of $\mathrm{N}, \mathrm{P}$ and $\mathrm{K}$ in plants varies with soil type, plant species, phenology and the chelating effects of other metals [53] and this can explain the differences observed between the accumulation of these elements in lettuce and carrots. The increase in $\mathrm{N}$ and $\mathrm{P}$ concentrations observed in the present study was in accordance with Bozkurt et al., who reported that maize fertilization with sewage sludge resulted in increased $\mathrm{N}$ and $\mathrm{P}$ content in both leaves and grains, mainly due to the improvement of soil conditions, $\mathrm{N}$ supply and rhizosphere aggregate stability [52]. With regard to $\mathrm{K}$ content in plant tissues, several authors reported that sewage sludge fertilization is not effective for its increase due to the 
high concentration of this element in soil $[52,53]$. Nevertheless, Samaras et al. showed an increased $\mathrm{K}$ content in cotton tissues after repeated sewage sludge application to the soil, probably due to the increased concentration of $\mathrm{K}$ in the soil [55].

\subsubsection{Leachate Characterization}

Leachate analysis was performed to evaluate the potential for groundwater contamination consequent to PDSS applications to the soil. Leachates from all the jars were collected after 20 days from the beginning of the agronomic trials and the results of their characterization are reported in Table 6.

Table 6. Main physico-chemical parameters and heavy metals in the leachate collected after 20 days of fertilization. $\mathrm{N}^{-\mathrm{NH}_{4}}{ }^{+}, \mathrm{Cr} \mathrm{VI}, \mathrm{Hg}$ and Be were under the detection limit of the method in all samples (0.5 $\mathrm{mg} \mathrm{L}^{-1}, 0.1 \mu \mathrm{g} \mathrm{L}^{-1}, 0.1 \mu \mathrm{g} \mathrm{L}-1$ and $0.1 \mu \mathrm{g} \mathrm{L}^{-1}$, respectively).

\begin{tabular}{ccccccc}
\hline Plant & Parameter & Unit & Control & PDSS $^{\mathbf{a}}$ & DCM $^{\mathbf{b}}$ & Limit Value $^{\mathbf{c}}$ \\
\hline Lettuce & $\mathrm{pH}$ & - & $7.3 \pm 0.0 \mathrm{~d}$ & $7.3 \pm 0.0$ & $7.4 \pm 0.0$ & $5.5-9.5$ \\
& $\mathrm{EC}$ & $\mathrm{mS} \mathrm{cm}^{-1}$ & $0.8 \pm 0.0$ & $0.9 \pm 0.1$ & $0.8 \pm 0.1$ & - \\
& $\mathrm{N}^{-N_{3}{ }^{-}}$ & $\mathrm{mg} \mathrm{L}^{-1}$ & $6 \pm 1 \mathrm{a}$ & $9 \pm 2 \mathrm{a}$ & $15 \pm 2 \mathrm{~b}$ & 20 \\
& $\mathrm{Cu}$ & $\mu \mathrm{g} \mathrm{L}^{-1}$ & $4.5 \pm 1.0$ & $3.4 \pm 0.5$ & $4.4 \pm 1.6$ & 100 \\
& $\mathrm{Zn}$ & $\mu \mathrm{g} \mathrm{L}^{-1}$ & $16 \pm 3$ & $15 \pm 4$ & $27 \pm 7$ & 500 \\
& $\mathrm{~Pb}$ & $\mu \mathrm{g} \mathrm{L}^{-1}$ & $0.1 \pm 0.0$ & $0.2 \pm 0.0$ & $0.2 \pm 0.0$ & 200 \\
& $\mathrm{Ni}$ & $\mu \mathrm{g} \mathrm{L}^{-1}$ & $80 \pm 5$ & $96 \pm 5$ & $85 \pm 2$ & 2000 \\
& $\mathrm{Total} \mathrm{Cr}$ & $\mu \mathrm{g} \mathrm{L}^{-1}$ & $118 \pm 0$ & $122 \pm 3$ & $121 \pm 1$ & 2000 \\
& $\mathrm{Cd}$ & $\mu \mathrm{g} \mathrm{L}^{-1}$ & $<0.1 \mathrm{e}$ & $<0.1$ & $0.1 \pm 0.0$ & 20 \\
& $\mathrm{As}$ & $\mu \mathrm{g} \mathrm{L}^{-1}$ & $0.6 \pm 0.2$ & $1.0 \pm 0.4$ & $0.6 \pm 0.3$ & 500 \\
& $\mathrm{Se}$ & $\mu \mathrm{g} \mathrm{L}^{-1}$ & $0.1 \pm 0.0$ & $0.1 \pm 0.0$ & $0.1 \pm 0.1$ & 30 \\
\hline \multirow{2}{*}{ Carrot } & $\mathrm{pH}^{-}$ & $7.2 \pm 0.1$ & $7.2 \pm 0.0$ & $7.3 \pm 0.0$ & $5.5-9.5$ \\
& $\mathrm{EC}$ & $\mathrm{mS} \mathrm{cm}^{-1}$ & $1.0 \pm 0.1$ & $1.0 \pm 0.1$ & $1.1 \pm 0.1$ & - \\
& $\mathrm{N}-\mathrm{NO}{ }^{-}$ & $\mathrm{mg} \mathrm{L}^{-1}$ & $10 \pm 0 \mathrm{a}$ & $11 \pm 3 \mathrm{a}$ & $13 \pm 1 \mathrm{~b}$ & 20 \\
$\mathrm{Cu}$ & $\mu \mathrm{g} \mathrm{L}^{-1}$ & $4.0 \pm 0.6$ & $4.0 \pm 0.6$ & $4.2 \pm 1.0$ & 100 \\
& $\mathrm{Zn}$ & $\mu \mathrm{g} \mathrm{L}^{-1}$ & $13 \pm 3$ & $18 \pm 2$ & $24 \pm 7$ & 500 \\
& $\mathrm{~Pb}$ & $\mu \mathrm{g} \mathrm{L}^{-1}$ & $0.2 \pm 0.0$ & $0.1 \pm 0.0$ & $0.2 \pm 0.0$ & 200 \\
$\mathrm{Ni}$ & $\mu \mathrm{g} \mathrm{L}^{-1}$ & $54 \pm 6$ & $92 \pm 10$ & $85 \pm 4$ & 2000 \\
& $\mathrm{Total} \mathrm{Cr}$ & $\mu \mathrm{g} \mathrm{L}^{-1}$ & $118 \pm 1$ & $122 \pm 1$ & $119 \pm 1$ & 2000 \\
$\mathrm{Cd}$ & $\mu \mathrm{g} \mathrm{L}^{-1}$ & $0.1 \pm 0.0$ & $<0.1$ & $0.1 \pm 0.0$ & 20 \\
$\mathrm{As}$ & $\mu \mathrm{g} \mathrm{L}^{-1}$ & $0.7 \pm 0.1$ & $0.9 \pm 0.2$ & $0.7 \pm 0.1$ & 500 \\
$\mathrm{Se}$ & $\mu \mathrm{g} \mathrm{L}^{-1}$ & $0.1 \pm 0.0$ & $0.1 \pm 0.0$ & $0.1 \pm 0.0$ & 30
\end{tabular}

a Pharmaceutical dried sewage sludge. ${ }^{b}$ Dried cattle manure. ${ }^{c}$ [56]. Limits for discharge of water in freshwater bodies. ${ }^{\mathrm{d}}$ Mean value $\pm \mathrm{SD}, n=4 .{ }^{\mathrm{e}}$ Detection limit of the method. Means in the same row followed by different letters $(a, b)$ are different at $p<0.05$.

The results of PDSS leachates were also compared to the leachates collected from the DCM fertilized jars and to the limits established by Italian regulations concerning the discharge of water in freshwater bodies [56].

$\mathrm{N}-\mathrm{NH}_{4}{ }^{+}$was under the detection limit $\left(0.5 \mathrm{mg} \mathrm{L}^{-1}\right)$ in all the leachates (both from lettuce and carrot jars), and no significant differences were found between the control and the PDSS leachates (from lettuce and carrot jars) with respect to $\mathrm{pH}, \mathrm{EC}$ and $\mathrm{N}$ $\mathrm{NO}_{3}{ }^{-}$. However, the $\mathrm{N}-\mathrm{NO}_{3}{ }^{-}$concentration in the leachates from DCM fertilized jars was significantly higher than that of the control and the PDSS leachates. The leaching of nitrates from manure-fertilized soils is well described in the literature and is mainly caused by the mineralization of organic $\mathrm{N}$ in soil, which is not followed by plant uptake [57]. In addition, organic fertilizers characterized by high amounts of ammonium- $\mathrm{N}$ can promote nitrate leaching in groundwater, as described by Forge et al. who compared compost and poultry manure as preplant soil amendments for the red raspberry [58]. They observed that manure-amended soils showed higher nitrate leaching than compost-amended soil, and they explained this result by taking into consideration the higher loading of ammonium-N 
in the manure treatment. In this work, PDSS fertilization resulted in lower nitrates leaching with respect to DCM fertilization probably due to the quality of the $\mathrm{N}$ input of the sewage sludge, which was completely represented by organic-N (Table 1).

With regard to heavy metal leaching, $\mathrm{Cr}$ VI, $\mathrm{Hg}$ and Be were under the detection limit of the method $\left(0.1 \mu \mathrm{g} \mathrm{L} \mathrm{L}^{-1}, 0.1 \mu \mathrm{g} \mathrm{L}^{-1}\right.$ and $0.1 \mu \mathrm{g} \mathrm{L} \mathrm{L}^{-1}$, respectively) in all the leachates analyzed (both from carrot and lettuce jars). No significant differences were measured among the heavy metal concentrations $(\mathrm{Cu}, \mathrm{Zn}, \mathrm{Pb}, \mathrm{Ni}$, total $\mathrm{Cr}, \mathrm{Cd}$, As and Se) in lettuce and carrots leachates collected from PDSS and DCM fertilized soils with respect to the control soils. This result was probably due to the low concentrations of heavy metals contained in both PDSS and DCM (Table 2), as well as to other factors affecting the mobility of heavy metals in soil (i.e., addition of organic matter) [59].

Summarizing, the analysis of leachates highlighted that PDSS might be considered as an environmentally friendly organic fertilizer characterized by lower nitrate leaching than DCM, which is a marketable organic fertilizer. Nevertheless, it should be highlighted that all the parameters analyzed $\left(\mathrm{pH}, \mathrm{N}-\mathrm{NH}_{4}{ }^{+}, \mathrm{N}_{-} \mathrm{NO}_{3}{ }^{-}\right.$and heavy metals) in leachates from PDSS and DCM fertilized soils complied with the limit values established by Italian regulations for the discharge of water in freshwater bodies.

\section{Conclusions}

A complete agronomic and environmental characterization of sewage sludge obtained from a pharmaceutical manufacturing process was carried out to highlight that the exclusion of all sewage sludge based on the component materials in the new European fertilizer regulation is in conflict with the principles of the circular bioeconomy.

PDSS showed higher agronomic and environmental value than other biomasses commonly used as organic fertilizers and which are now included in the list of component materials in the European framework of fertilizers (i.e., digestate, compost, manure). Sewage sludge produced from controlled and standardized wastewater treatment plants can represent a valuable source of nutrients, which can be recycled safely in agriculture. The origin paradigm used in the actual European fertilizer regulation should be modified towards a quality paradigm, where component materials are chosen based on their agronomic and environmental qualities as well as their origin.

Author Contributions: Conceptualization, M.C. and F.A.; methodology, M.C. and F.A.; investigation, M.C. and P.D.N.; data curation, M.C.; writing-original draft preparation, M.C. and F.A.; writingreview and editing, F.A. and S.S.; supervision, F.A.; funding acquisition, F.A. All authors have read and agreed to the published version of the manuscript.

Funding: This work was founded by: ACSDobfar S.p.A., contract number: CTE_NAZPR20FADAN_05.

Data Availability Statement: Data is contained within the article.

Conflicts of Interest: The authors declare no conflict of interest.

\section{References}

1. Organization of the United Nations. Department of Economic and Social Affairs, Population Division. World Population Prospects 2019: Highlights. Available online: https:/ / population.un.org/wpp/Publications/Files/WPP2019_Highlights.pdf (accessed on 6 October 2021).

2. Organization of the United Nations. Take Action for the Sustainable Development Goals-United Nations Sustainable Development. Available online: https://www.un.org/sustainabledevelopment/sustainable-development-goals/ (accessed on 6 October 2021).

3. FAO. Food Outlook-Biannual Report on Global Food Markets, Food Outlook—Biannual Report on Global Food Markets. Available online: https:/ / doi.org/10.4060/cb1993en (accessed on 6 October 2021).

4. FAO. World Fertilizer Trends and Outlook to 2022. Available online: https://doi.org/10.4060/ca6746en (accessed on 6 October 2021).

5. Cherkasov, N.; Ibhadon, A.O.; Fitzpatrick, P. A review of the existing and alternative methods for greener nitrogen fixation. Chem. Eng. Process. 2015, 90, 24-33. [CrossRef]

6. Günther, S.; Grunert, M.; Müller, S. Overview of recent advances in phosphorus recovery for fertilizer production. Eng. Life Sci. 2018, 18, 434-439. [CrossRef] [PubMed] 
7. Khan, M.N.; Mohammad, F. Eutrophication: Challenges and solutions. In Eutrophication: Causes, Consequences and Control; Abid, A.A., Saravajeet, S.G., Eds.; Springer Science \& Business Media: Berlin, Germany, 2014; pp. 1-15. [CrossRef]

8. Wang, Y.; Zhu, Y.; Zhang, S.; Wang, Y. What could promote farmers to replace chemical fertilizers with organic fertilizers? J. Clean. Prod. 2018, 199, 882-890. [CrossRef]

9. Pigoli, A.; Zilio, M.; Tambone, F.; Mazzini, S.; Schepis, M.; Meers, E.; Schoumans, O.; Giordano, A.; Adani, F. Thermophilic anaerobic digestion as suitable bioprocess producing organic and chemical renewable fertilizers: A full-scale approach. Waste Manag. 2021, 124, 356-367. [CrossRef]

10. Zilio, M.; Pigoli, A.; Rizzi, B.; Geromel, G.; Meers, E.; Schoumans, O.; Giordano, A.; Adani, F. Measuring ammonia and odours emissions during full field digestate use in agriculture. Sci. Total Environ. 2021, 782, 146882. [CrossRef]

11. European Commission. Regulation (EU) 2019/1009 Fertilizer Products. Off. J. Eur. Union 2019, 170.

12. Fijalkowski, K.; Rorat, A.; Grobelak, A.; Kacprzak, M.J. The presence of contaminations in sewage sludge-The current situation. J. Environ. Manag. 2017, 203, 1126-1136. [CrossRef]

13. Nissim, W.G.; Cincinelli, A.; Martellini, T.; Alvisi, L.; Palm, E.; Mancuso, S.; Azzarello, E. Phytoremediation of sewage sludge contaminated by trace elements and organic compounds. Environ. Res. 2018, 164, 356-366. [CrossRef]

14. Meng, X.Z.; Venkatesan, A.K.; Ni, Y.L.; Steele, J.C.; Wu, L.L.; Bignert, A.; Bergman, Å.; Halden, R.U. Organic Contaminants in Chinese Sewage Sludge: A Meta-Analysis of the Literature of the Past 30 Years. Environ. Sci. Technol. 2016, 50, 5454-5466. [CrossRef]

15. Rolsky, C.; Kelkar, V.; Driver, E.; Halden, R.U. Municipal sewage sludge as a source of microplastics in the environment. Curr. Opin. Environ. Sci. Health 2019, 14, 16-22. [CrossRef]

16. Yang, G.H.; Zhu, G.Y.; Li, H.L.; Han, X.M.; Li, J.M. Accumulation and bioavailability of heavy metals in a soil-wheat/maize system with long-term sewage sludge amendments. J. Integr. Agric. 2018, 17, 1861-1870. [CrossRef]

17. Campo, G.; Cerutti, A.; Lastella, C.; Leo, A.; Panepinto, D.; Zanetti, M.; Ruffino, B. Production and destination of sewage sludge in the Piemonte region (Italy): The results of a survey for a future sustainable management. Int. J. Environ. Res. Public Health 2021, 18, 3556. [CrossRef] [PubMed]

18. Zittel, R.; da Silva, C.P.; Domingues, C.E.; Seremeta, D.C.H.; da Cunha, K.M.; de Campos, S.X. Availability of nutrients, removal of nicotine, heavy metals and pathogens in compounds obtained from smuggled cigarette tobacco compost associated with industrial sewage sludge. Sci. Total Environ. 2019, 699, 134377. [CrossRef]

19. Alvarenga, P.; Mourinha, C.; Farto, M.; Santos, T.; Palma, P.; Sengo, J.; Morais, M.C.; Cunha-Queda, C. Sewage sludge, compost and other representative organic wastes as agricultural soil amendments: Benefits versus limiting factors. Waste Manag. 2015, 40, 44-52. [CrossRef]

20. Cucina, M.; Tacconi, C.; Ricci, A.; Pezzolla, D.; Sordi, S.; Zadra, C.; Gigliotti, G. Evaluation of benefits and risks associated with the agricultural use of organic wastes of pharmaceutical origin. Sci. Total Environ. 2018, 613-614, 773-782. [CrossRef]

21. Cucina, M.; Ricci, A.; Zadra, C.; Pezzolla, D.; Tacconi, C.; Sordi, S.; Gigliotti, G. Benefits and risks of long-term recycling of pharmaceutical sewage sludge on agricultural soil. Sci. Total Environ. 2019, 695, 133762. [CrossRef] [PubMed]

22. Scaglia, B.; Tambone, F.; Corno, L.; Orzi, V.; Lazzarini, Y.; Garuti, G.; Adani, F. Potential agronomic and environmental properties of thermophilic anaerobically digested municipal sewage sludge measured by an unsupervised and a supervised chemometric approach. Sci. Total Environ. 2018, 637-638, 791-802. [CrossRef]

23. Congilosi, J.L.; Aga, D.S. Review on the fate of antimicrobials, antimicrobial resistance genes, and other micropollutants in manure during enhanced anaerobic digestion and composting. J. Hazard. Mater. 2020, 405, 123634. [CrossRef] [PubMed]

24. European Commission. Directive (EU) 2018/851 of the European Parliament and of the Council of 30 May 2018 amending Directive 2008/98/EC on waste (Text with EEA relevance). Off. J. Eur. Union 2018, 150, 109-140.

25. Presidency of the Council of Ministers. Implementation of Directive No. 86/278/EEC Concerning the Protection of the Environment, in Particular of the Soil, in the Use of Purification Sludge in Agriculture; Gazzetta Ufficiale: Rome, Italy, 2010.

26. Presidency of the Council of Ministers. Legislative Decree 29 April 2010, No. 75-Reorganization and Revision of the Regulations on Fertilizers, Pursuant to Article 13 of the Law of 7 July 2009, No. 88; Gazzetta Ufficiale: Rome, Italy, 2010.

27. Kacprzak, M.; Neczaj, E.; Fijałkowski, K.; Grobelak, A.; Grosser, A.; Worwag, M.; Rorat, A.; Brattebo, H.; Almås, Å.; Singh, B.R. Sewage sludge disposal strategies for sustainable development. Environ. Res. 2017, 156, 39-46. [CrossRef]

28. Lombardi, L.; Nocita, C.; Bettazzi, E.; Fibbi, D.; Carnevale, E. Environmental comparison of alternative treatments for sewage sludge: An Italian case study. Waste Manag. 2017, 69, 365-376. [CrossRef]

29. American Public Health Association (APHA); Water Environment Federation. Standard Methods for the Examination of Water and Wastewater; American Public Health Association: Washington, DC, USA, 2017.

30. ANPA. Metodi di Analisi del Compost; ISPRA, Manuali e Linee Guida: Rome, Italy, 2001.

31. United States Environmental Protection Agency (USEPA). Method 3051A-Microwave Assisted Acid Digestion of Sediments, Sludges, Soils And Oils; United States Environmental Protection Agency: Washington, DC, USA, 2007.

32. Gu, Y.G. Calculation of beryllium toxic factor for potential ecological risk evaluation: A case study. Environ. Technol. Innov. 2021, 21, 101361. [CrossRef]

33. APAT. Metodi microbiologici di analisi del compost. In Manuali e Linee Guida 20/2003. APAT_Agenzia per la Protezione Dell'ambiente e per i Servizi Tecnici; APAT, Manuali e Linee Guida: Rome, Italy, 2003. 
34. International Organization for Standardization (ISO). Water Quality-Determination of 16 Polycyclic Aromatic Hydrocarbons (PAH) in Water-Method Using Gas Chromatography with Mass Spectrometric Detection (GC-MS); ISO: 28540:2011; International Organization for Standardization (ISO): Geneva, Switzerland, 2011.

35. International Organization for Standardization (ISO). Water Quality—Determination of Benzene and Some Derivatives—Part 1: HeadSpace Gas Chromatographic Method; ISO: 11423-1:1997; International Organization for Standardization (ISO): Geneva, Switzerland, 1997.

36. International Organization for Standardization (ISO). Sludge, Treated Biowaste and Soil-Digestion of Aqua Regia Soluble Fractions of Elements; ISO: 54321:2020; International Organization for Standardization (ISO): Geneva, Switzerland, 2020.

37. International Organization for Standardization (ISO). Soil, Treated Biowaste and Sludge-Determination of Polychlorinated Biphenyls (PCB) by Gas Chromatography with Mass Selective Detection (GC-MS) and Gas Chromatography with Electron-Capture Detection (GC-ECD); ISO: 13876:2013; International Organization for Standardization (ISO): Geneva, Switzerland, 2013.

38. Ente Nazionale Italiano di Unificazione (UNI). Caratterizzazione dei Rifiuti-Determinazione di Policlorodibenzo-P-Diossine (PCDD) e Policlorodibenzofurani (PCDF) in Rifiuti Solidi; UNI 11199:2007; Ente Nazionale Italiano di Unificazione (UNI): Milan, Italy, 2007.

39. Ente Nazionale Italiano di Unificazione (UNI). Characterization of Waste-Determination of Hydrocarbon Content in the Range of C10 to C40 by Gas Chromatography; UNI EN 14039:2005; Ente Nazionale Italiano di Unificazione (UNI): Milan, Italy, 2005.

40. International Organization for Standardization (ISO). Soil Quality-Determination of Water Retention Characteristics-Laboratory Methods; ISO 11274:2019; International Organization for Standardization (ISO): Geneva, Switzerland, 2019.

41. Garfí, M.; Martí-Herrero, J.; Garwood, A.; Ferrer, I. Household anaerobic digesters for biogas production in Latin America: A review. Renew. Sust. Energ. Rev. 2016, 60, 599-614. [CrossRef]

42. Manirakiza, E.; Ziadi, N.; St. Luce, M.; Hamel, C.; Antoun, H.; Karam, A. Nitrogen mineralization and microbial biomass carbon and nitrogen in response to co-application of biochar and paper mill biosolids. App. Soil Ecol. 2019, 142, 90-98. [CrossRef]

43. Alburquerque, J.A.; de la Fuente, C.; Campoy, M.; Carrasco, L.; Nájera, I.; Baixauli, C.; Caravaca, F.; Roldán, A.; Cegarra, J.; Bernal, M.P. Agricultural use of digestate for horticultural crop production and improvement of soil properties. Eur. J. Agron. 2012, 43, 119-128. [CrossRef]

44. Cucina, M.; Tacconi, C.; Sordi, S.; Pezzolla, D.; Gigliotti, G.; Zadra, C. Valorization of a pharmaceutical organic sludge through different composting treatments. Waste Manag. 2018, 74, 203-212. [CrossRef]

45. Wei, Y.; Liu, Y. Effects of sewage sludge compost application on crops and cropland in a 3-year field study. Chemosphere 2005, 59, 1257-1265. [CrossRef]

46. Romdhana, M.H.; Lecomte, D.; Ladevie, B.; Sablayrolles, C. Monitoring of pathogenic microorganisms contamination during heat drying process of sewage sludge. Process Saf. Environ. Prot. 2009, 87, 377-386. [CrossRef]

47. Heinonen-Tanski, H.; Mohaibes, M.; Karinen, P.; Koivunen, J. Methods to reduce pathogen microorganisms in manure. Livest. Sci. 2006, 102, 248-255. [CrossRef]

48. Avery, L.M.; Booth, P.; Campbell, C.; Tompkins, D.; Hough, R.L. Prevalence and survival of potential pathogens in sourcesegregated green waste compost. Sci. Total Environ. 2012, 431, 128-138. [CrossRef]

49. Perera, M.A.D.N.; Qin, W.; Yandeau-Nelson, M.; Fan, L.; Dixon, P.; Nikolau, B.J. Biological origins of normal-chain hydrocarbons: A pathway model based on cuticular wax analyses of maize silks. Plant J. 2010, 64, 618-632. [CrossRef]

50. Agenzia Regionale per la protezione dell'ambiente del Veneto. Risultati del Monitoraggio Eseguito nel 2013 Delle Caratteristiche dei Digestati Prodotti da Impianti per la Produzione di Biogas che Trattano Liquami Zootecnici Situati nel Veneto; ARPA Veneto: Padova, Italy, 2013.

51. Verlicchi, P.; Zambello, E. Pharmaceuticals and personal care products in untreated and treated sewage sludge: Occurrence and environmental risk in the case of application on soil-A critical review. Sci. Total Environ. 2015, 538, 750-767. [CrossRef] [PubMed]

52. Bozkurt, M.A.; Akdeniz, H.; Keskin, B.; Yilmaz, I.H. Possibilities of using sewage sludge as nitrogen fertilizer for maize. Acta Agric. Scand. Sect. B-Soil Plant Sci. 2006, 56, 143-149. [CrossRef]

53. Singh, R.P.; Agrawal, M. Potential benefits and risks of land application of sewage sludge. Waste Manag. 2008, 28, 347-358. [CrossRef]

54. Nozzi, V.; Graber, A.; Schmautz, Z.; Mathis, A.; Junge, R. Nutrient management in aquaponics: Comparison of three approaches for cultivating lettuce, mint and mushroom herb. Agronomy 2018, 8, 27. [CrossRef]

55. Samaras, V.; Tsadilas, C.D.; Stamatiadis, S. Effects of repeated application of municipal sewage sludge on soil fertility, cotton yield, and nitrate leaching. Agron. J. 2008, 100, 477-483. [CrossRef]

56. Presidency of the Council of Ministers. Decreto Legislativo 3 Aprile 2006, N. 152: Norme in Materia Ambientale; Gazzetta Ufficiale: Rome, Italy, 2006.

57. Sogn, T.A.; Dragicevic, I.; Linjordet, R.; Krogstad, T.; Eijsink, V.G.H.; Eich-Greatorex, S. Recycling of biogas digestates in plant production: NPK fertilizer value and risk of leaching. Int. J. Recyc. Org. Waste Agric. 2018, 7, 49-58. [CrossRef]

58. Forge, T.; Kenney, E.; Hashimoto, N.; Neilsen, D.; Zebarth, B. Compost and poultry manure as preplant soil amendments for red raspberry: Comparative effects on root lesion nematodes, soil quality and risk of nitrate leaching. Agric. Ecosyst. Environ. 2016, 223, 48-58. [CrossRef]

59. Fang, W.; Wei, Y.; Liu, J. Comparative characterization of sewage sludge compost and soil: Heavy metal leaching characteristics. J. Hazard. Mater. 2016, 310, 1-10. [CrossRef] 